\title{
Effect of One Month Ketoconazole Treatment on GH, Cortisol and ACTH Release After Ghrelin, GHRP-6 and GHRH Administration in Patients With Cushing's Disease
}

\section{artigo original}

\author{
SILVIA R. CORREA-SILVA \\ SÉRGIO O. NASCIF \\ MARCOS R. SILVA \\ PatrícIa MOLICa \\ ANA-MARIA J. LeNGYel
}

Division of Endocrinology, Universidade Federal de São Paulo, SP.

Recebido em 28/03/07 Aceito em 21/06/07

\section{ABSTRACT}

GH responses to ghrelin, GHRP-6, and GHRH in Cushing's disease (CD) are markedly blunted. There is no data about the effect of reduction of cortisol levels with steroidogenesis inhibitors, like ketoconazole, on $\mathrm{GH}$ secretion in $\mathrm{CD}$. ACTH levels during ketoconazole treatment are controversial. The aims of this study were to compare the GH response to ghrelin, GHRP-6, and GHRH, and the ACTH and cortisol responses to ghrelin and GHRP- 6 before and after one month of ketoconazole treatment in 6 untreated patients with $\mathrm{CD}$. Before treatment peak GH $(\mu \mathrm{g} / \mathrm{L}$; mean $\pm \mathrm{SEM})$ after ghrelin, GHRP-6, and GHRH administration was $10.0 \pm 4.5 ; 3.8 \pm 1.6$, and $0.6 \pm 0.2$, respectively. After one month of ketoconazole there was a significant decrease in urinary cortisol values (mean reduction: 75\%), but GH responses did not change $(7.0 \pm 2.0 ; 3.1 \pm$ $0.8 ; 0.9 \pm 0.2$, respectively). After treatment, there was a significant reduction in cortisol $(\mu \mathrm{g} / \mathrm{dL}$ ) responses to ghrelin (before: $30.6 \pm 5.2$; after: $24.2 \pm 5.1$ ). No significant changes in ACTH $(\mathrm{pg} / \mathrm{mL})$ responses before (ghrelin: $210.9 \pm 69.9$; GHRP-6: $199.8 \pm 88.8$ ) and after treatment (ghrelin: $159.7 \pm 40.3$; GHRP-6: 227 \pm 127.2 ) were observed. In conclusion, after short-term ketoconazole treatment there are no changes in GH or ACTH responses, despite a major decrease of cortisol levels. A longer period of treatment might be necessary for the recovery of pituitary function. (Arq Bras Endocrinol Metab 2007;51/7:1110-1117)

Keywords: Ghrelin; GHRP-6; GHRH; GH; ACTH; Cushing's disease

\section{RESUMO}

Efeito do Tratamento com Ketoconazole por um Mês na Liberação de GH, Cortisol e ACHT Após Administração de GHrelin, GHRP-6 e GHRH em Pacientes com Síndrome de Cushing.

$\mathrm{Na}$ doença de Cushing (DC), as respostas do GH à ghrelina, ao GHRP-6 e ao GHRH estão diminuídas. Não existem dados sobre o efeito da redução dos níveis de cortisol, após cetoconazol, na secreção de GH na DC. Nessa situação, os níveis de ACTH são variáveis. Os objetivos do estudo são comparar as respostas do $\mathrm{GH}$ à administração de ghrelina, GHRP-6 e GHRH, e de ACTH e cortisol à ghrelina e ao GHRP-6 antes e após um mês de tratamento com cetoconazol em 6 pacientes com DC não tratados. Antes do tratamento, o pico de $\mathrm{GH}(\mu \mathrm{g} / \mathrm{L} ;$ média $\pm \mathrm{EPM}$ ) após a administração de ghrelina, GHRP-6 e GHRH foi de $10,0 \pm 4,5 ; 3,8 \pm 1,6$ e 0,6 $\pm 0,2$, respectivamente. Após um mês de cetoconazol, ocorreu diminuição significante do cortisol urinário (redução média: $75 \%)$, mas as respostas de GH permaneceram inalteradas $(7,0 \pm 2,0 ; 3,1 \pm 0,8$; $0,9 \pm 0,2$, respectivamente). Após o tratamento, houve redução da resposta de cortisol ( $\mu \mathrm{g} / \mathrm{dL}$ ) à ghrelina (antes: $30,6 \pm 5,2$; após: $24,2 \pm 5,1$ ), mas não ocorreram mudanças nas respostas de ACTH (pg/mL) (ghrelina antes: 210,9 \pm 69,9; após: 159,7 \pm 40,3; GHRP-6 antes: 199,8 \pm 88,8; após: $227 \pm 127,2)$. Assim, o tratamento a curto prazo com cetoconazol não modificou as respostas de $\mathrm{GH}$ ou ACTH, apesar da redução do cortisol. Para a recuperação da função hipofisária deve ser necessário um período de tratamento maior. (Arq Bras Endocrinol Metab 2007;51/7:1110-1117)

Descritores: Ghrelina; GHRP-6; GHRH; GH; ACTH; Doença de Cushing 
G H SECRETION IS CLASSICALLY modulated by an interplay between GHRH and SRIF. However, several studies have suggested that GH secretagogues (GHS) might also have a role in this process, acting at both hypothalamic and pituitary receptors $(1,2)$. Ghrelin, the endogenous ligand of this receptor, is present both in the stomach and in the hypothalamus, mainly in the arcuate nucleus $(3,4)$. The active form of ghrelin is acylated and this peptide has a different chemical structure than GHS (3). Ghrelin can cross the blood-brain barrier (5) and is able to induce GH release in a potent manner in animals and humans after i.v. injection (6,7). It also increases circulating ACTH and cortisol levels (7). The main site of action of ghrelin and GHS is the hypothalamus, as there is a major decrease in their GH-releasing ability in hypothalamicpituitary disconnection, which also abolishes the ACTH and cortisol rise $(8,9)$.

It is well known that glucocorticoid excess impairs GH secretion (10). It has been previously shown that $\mathrm{GH}$ responses to several stimuli, including ghrelin, GHRP-6, and GHRH, are severely blunted in patients with Cushing's disease (CD) (10-15). The mechanisms involved in the inhibitory effect of longterm endogenous glucocorticoid excess on GH secretion are as yet unclear. High glucocorticoid levels could interfere with hypothalamic and/or pituitary GH-releasing pathways. A decrease in hypothalamic GHRH secretion (16) and a direct effect of glucocorticoids at the somatotroph (17) could be involved.

Patients with CD have an increased ACTH and cortisol responsiveness to ghrelin and GHRP-6 compared to normal subjects (10). This could be due to direct effect of these peptides on GHS-R (growth hormone secretagogue receptor) in the corticotroph adenoma (18), while in normal subjects a hypothalamic site of action has been suggested (19).

Acute clinical interventions such as the inhibition of free fatty acid synthesis (20) and short-term dietary restriction (19) are able to increase GH secretion in CD. This suggests that the secretory ability of the somatotroph can be restored in these patients. However, there are controversial results about the GH secretory state in CD after remission of hypercortisolism induced by transphenoidal surgery or radiotherapy (21-27).

There are no studies evaluating $\mathrm{GH}$ secretion in CD during clinical treatment of hypercortisolism with steroidogenesis inhibitors. Ketoconazole is a steroidogenesis inhibitor that has been used for clinical treatment of hypercortisolism for two decades. This compound is able to normalize cortisol levels in $70 \%$ of adult patients with CD (28). It is a safe drug, causing very rarely hepatic damage. Its major advantage is its ability to lower rapidly 24-hour urinary cortisol levels, which allows dose adjustments within the first week of treatment (29).

Conflicting results about basal and CRH-stimulated ACTH levels in patients with CD were reported after ketoconazole treatment (29-35). There are no studies about ACTH release after ghrelin and GHRP6 during ketoconazole use in CD.

As the findings about $\mathrm{GH}$ and ACTH release during ketoconazole treatment in patients with CD are controversial, the aims of this work were to evaluate $\mathrm{GH}, \mathrm{ACTH}$, and cortisol release after ghrelin and GHRP-6 administration before and after one month of ketoconazole use. GHRH-induced $\mathrm{GH}$ release was also studied, as this peptide stimulates GH via different mechanisms than those used by GHS.

\section{MATERIAL AND METHODS}

\section{Subjects}

Six patients with Cushing's disease ( 5 women and 1 men) were studied ( 5 micro and 1 macroadenoma). Their mean age was $34.1 \pm 5.1$ years (range: $19-56)$ and their mean body mass index (BMI) was $27.4 \pm 1.0 \mathrm{~kg} / \mathrm{m}^{2}$ (range: 23.9-31.6). All patients were previously untreated. The diagnosis of Cushing's disease was established on the basis of clinical features and standard hormonal criteria, including increased free urinary cortisol excretion, lack of suppression of serum cortisol after low-dose dexamethasone test ( $1 \mathrm{mg}$ orally overnight), normal or high basal plasma ACTH and serum cortisol levels at 08:00 h, and positive DDAVP test. Magnetic resonance imaging (MRI) of the sellar region showed a pituitary adenoma in all patients. After the end of the experimental protocol, the patients were submitted to transphenoidal surgery and the diagnosis of ACTH-secreting tumor was confirmed by positive ACTH immunostaining of the excised pituitary adenoma. All patients had normal renal function and one had secondary diabetes mellitus treated with metformin and insulin.

Ten normal subjects ( 4 women and 6 men) with a mean age of $33.5 \pm 3.3$ years (range: $20-47$ ) and mean BMI of $24.4 \pm 1.1 \mathrm{~kg} / \mathrm{m}^{2}$ (range: $19.5-30.8$ ) were also studied. They were free of any medication at the time of the study protocol. The women were tested in the early follicular phase of their menstrual cycle.

\section{Study protocol}

The experimental protocol was approved by the ethics committee of Universidade Federal de São Paulo, and all subjects gave prior informed consent. Each subject was submitted to three tests, in random order, with a minimum interval of 48 hours between them, either receiving ghrelin (Neosystem, 
Strasbourg, France), GHRP-6 (Bachem, San Carlos, USA) or GHRH (1-29)NH2 (Clinalfa, Läufelfingen, Switzerland). Patients with CD were studied before and after treatment with ketoconazole for one month. Ketoconazole was given at a dose of $400 \mathrm{mg} /$ day initially, administered twice or three times a day. After one week of treatment the response to the drug was evaluated by measurements of urinary cortisol and the dose of ketoconazole was titrated accordingly (300-600 mg/day).

All tests were performed after an overnight fast, and the subjects remained recumbent throughout. At 08:00 h an indwelling catheter was inserted into an antecubital vein and was kept patent by a slow saline infusion. The tests started 45 minutes later. After the first blood sample, each subject received ghrelin at a dose of $1 \mu \mathrm{g} / \mathrm{kg}$ i.v., GHRP- 6 at the same dose or GHRH at a dose of $100 \mu \mathrm{g}$ i.v. Blood samples were obtained every 15 minutes until 120 minutes for hormonal determinations.

\section{Assays}

Serum GH was measured in duplicate by an immunofluorometric assay (Wallac, Turku, Finland). The sensitivity of the method is $0.01 \mu \mathrm{g} / \mathrm{L}$, with mean inter- and intra-assay coefficients of variation $(\mathrm{CV})$ of $7 \%$ and $6.7 \%$ respectively. An immunochemiluminometric assay (Diagnostic Prod. Corporation, Los Angeles, USA) was used to measure plasma ACTH. The sensitivity of the method is $5 \mathrm{pg} / \mathrm{mL}$, with mean inter- and intra-assay $\mathrm{CV}$ of $3.6 \%$ and $2.8 \%$ respectively. Serum cortisol levels were measured in duplicate by an imunofluorometric assay (Wallac, Turku, Finland), with sensitivity of $0.2 \mu \mathrm{g} / \mathrm{L}$, and mean inter and intra-assay $\mathrm{CV}$ of $8.2 \%$ and $6.2 \%$ respectively.

Urinary cortisol was measured by radioimmunoassay (DSL 2100 Active Genese, Texas, USA) in 4 patients. The sensitivity of the method is $0.3 \mu \mathrm{g} / \mathrm{L}$, with mean inter- and intra-assay $\mathrm{CV}$ of $9.5 \%$ and $8.4 \%$ respectively. In the other 2 patients an immunochemiluminometric assay was used (Bayer ADVIA Centaur, Tarrytown, USA), with sensivity of $0.2 \mu \mathrm{g} / \mathrm{L}$ and mean inter- and intra-assay $\mathrm{CV}$ of $3.6 \%$ and $3.3 \%$ respectively.

\section{Statistical analysis}

Friedman's analysis of variance was performed to compare $\mathrm{GH}$, cortisol, and ACTH levels after the injection of each peptide and to compare GH responses in the same group. The Wilcoxon signed rank test was used for comparisons within the same group before and after treatment and for analysis of ACTH and cortisol values after stimulation. The area under the curve (AUC) was calculated by trapezoidal integration. Undetectable $\mathrm{GH}(\mu \mathrm{g} / \mathrm{L})$ and ACTH $(\mathrm{pg} / \mathrm{mL})$ values were considered to be equal to 0.01 and 5 respectively, for statistical purposes. Because of changes in the assays during the study period, urinary cortisol values were analyzed as percentual reduction. $\mathrm{P}<0.05$ was considered statistically significant. Results are reported as mean \pm S.E.M (standard error of the mean).

\section{RESULTS}

After one month of ketoconazole treatment all patients showed a decrease in urinary cortisol levels (mean reduction: $75 \%$ ) and in five patients (83\%) these values reached the normal range.

Before treatment, patients with CD showed higher mean peak $\mathrm{GH}(\mu \mathrm{g} / \mathrm{L}$; mean \pm S.E.M $)$ values after ghrelin administration $(10.0 \pm 4.5)$ than after GHRP-6 (3.8 \pm 1.6$)$ and GHRH injection $(0.6 \pm 0.2)$. However, these responses were significantly lower than those obtained in controls (ghrelin: $58.3 \pm 12.1$; GHRP-6: $22.9 \pm 4.8$; GHRH: $11.3 \pm 3.7$ ) (figure 1).

After ketoconazole treatment, $\mathrm{GH}$ responses to ghrelin (peak: $7.0 \pm 2.0)$, GHRP-6 (3.1 \pm 0.8$)$, and GHRH $(0.9 \pm 0.2)$ did not change and remained lower than in controls (figure 1), while there was a trend to increased $\mathrm{GH}$ responses to GHRH only in terms of AUC values (before: $40 \pm 12 \mu \mathrm{g} / \mathrm{L} .120 \mathrm{~min}$; after: $59 \pm$ $13 ; \mathrm{P}=0.06)$. The same results were obtained even when the data was analyzed excluding the patient that did not normalize urinary cortisol levels after treatment.

Before ketoconazole, patients with CD had similar ACTH $(\mathrm{pg} / \mathrm{mL})$ and cortisol $(\mu \mathrm{g} / \mathrm{dL})$ values after ghrelin (ACTH: $210.9 \pm 69.9$; cortisol: $30.6 \pm 5.2)$ and GHRP-6 (ACTH: $199.8 \pm 88.8$; cortisol: $28.8 \pm 5.9$ ) administration. Peak ACTH responses to ghrelin and GHRP-6 in CD were higher than those obtained in controls (ghrelin: $79.2 \pm 26.8$; GHRP-6: $23.6 \pm 5.7$ ) (figure $2)$. Peak cortisol values were also higher in CD compared to controls after ghrelin $(17.3 \pm 1.3)$ and GHRP-6 (13.3 \pm 0.9 ) injection, although the latter response was only significant in terms of AUC values (data not shown).

After ketoconazole treatment, no significant changes in peak ACTH values after both ghrelin (159.7 \pm 40.3) and GHRP-6 (227 \pm 127.2$)$ injection were observed. There was a decrease in peak cortisol response to ghrelin $(24.2 \pm 5.1)$, which became similar to that obtained in controls. This decrease was also observed in cortisol values after GHRP-6 injection $(23.0 \pm 4.4)$, although not reaching statistical significance (figure 2).

There were no changes in basal cortisol or ACTH values after treatment. No differences in BMI were seen before and after ketoconazole administration.

\section{Side effects}

Hunger sensation was observed in some patients after ghrelin administration. Transient facial flushing was also seen after ghrelin, GHRP-6, and GHRH in some cases. None of the patients had an increase in hepatic transaminases after ketoconazole administration. Two patients had symptoms of adrenal insufficiency in the first week of ketoconazole treatment. 


\section{Ghrelin}
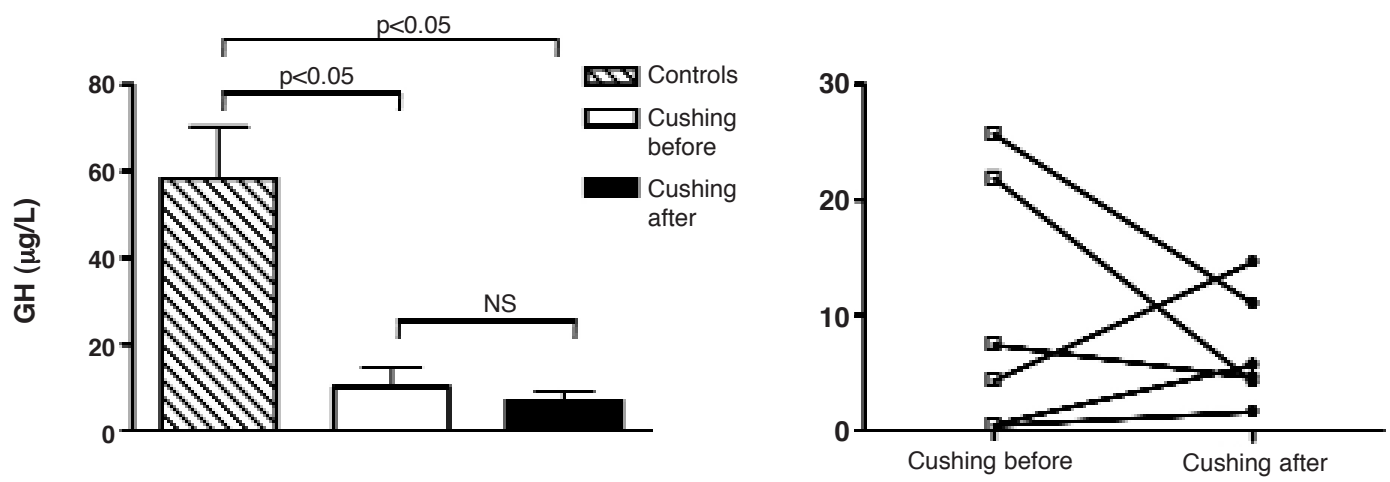

\section{GHRP-6}
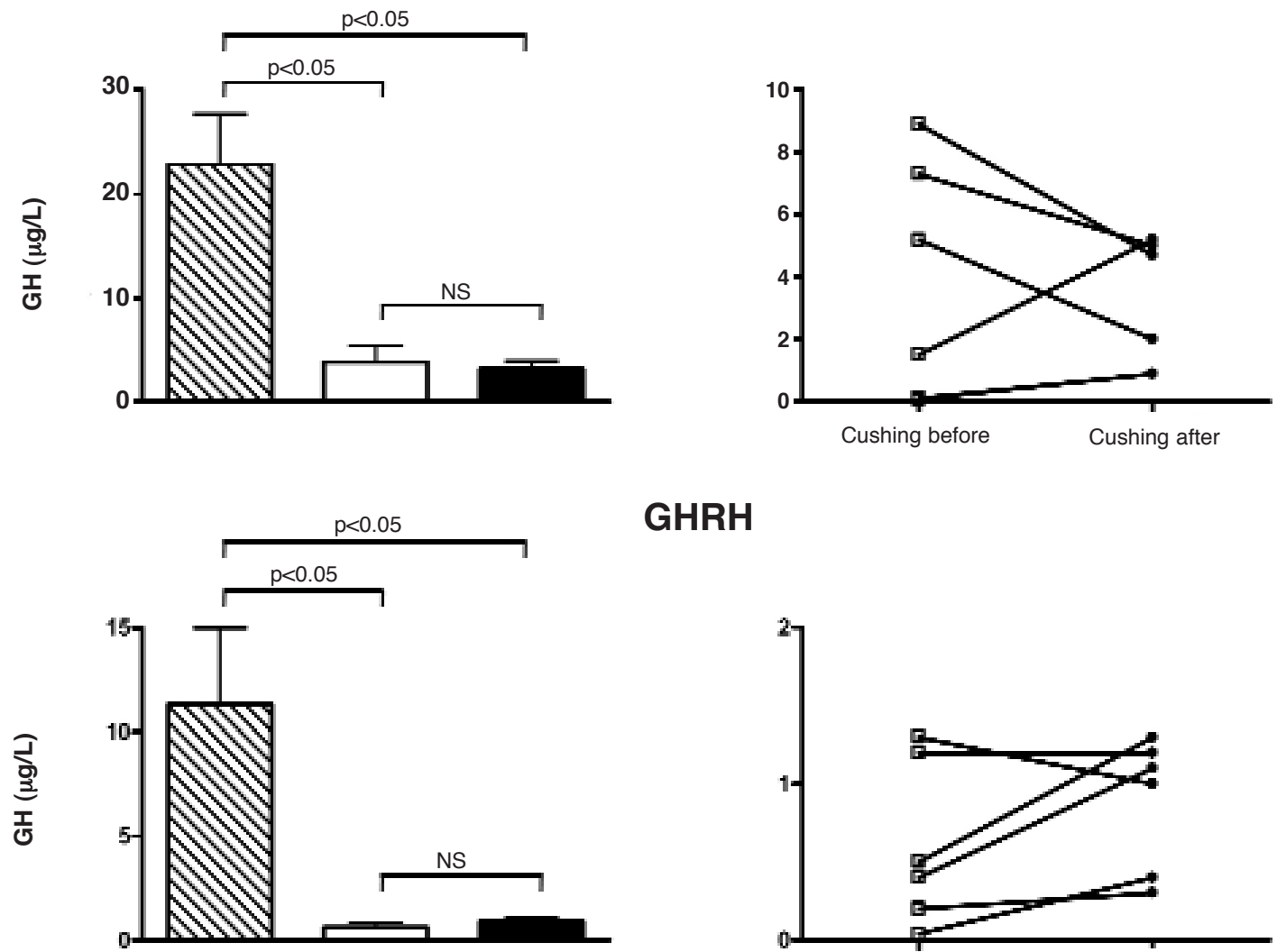

\section{GHRH}

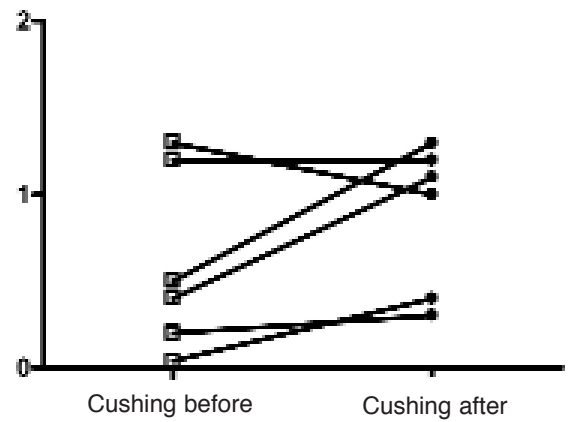

Figure 1. (A) Mean peak GH values after ghrelin, GHRP-6, and GHRH in controls $(n=10)$ and in $C D(n=6)$ before and after 1 month of ketoconazole treatment (mean \pm S.E.M). (B) Individual GH levels after ghrelin, GHRP-6, and GHRH before and after treatment in $C D$. 
A

Ghrelin

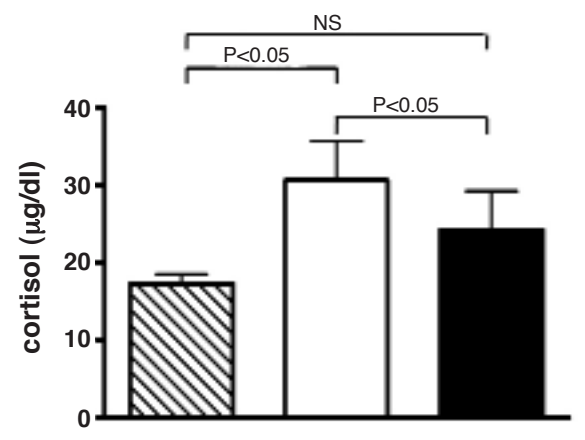

B

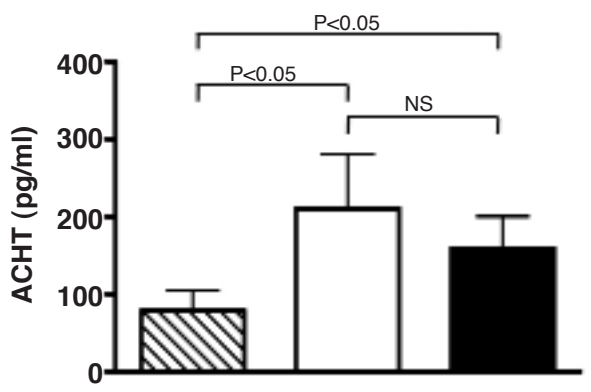

GHRP-6

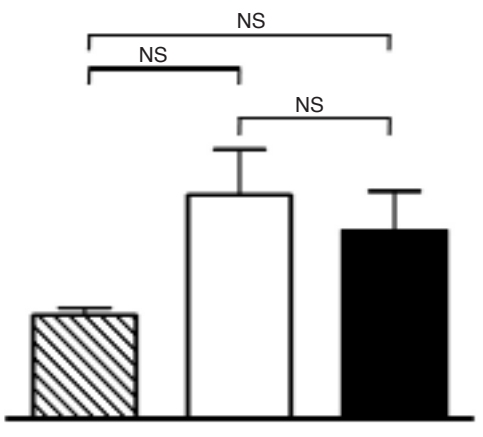

GHRP-6

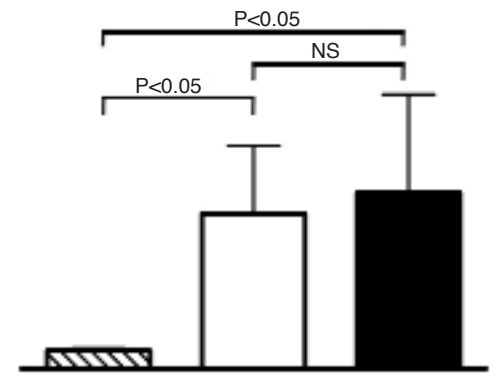

Figure 2. Mean peak cortisol (A) and ACTH (B) values after ghrelin and GHRP-6 in controls $(n=10)$ and in CD $(n=6)$ before and after 1 month of ketoconazole treatment (mean \pm S.E.M).

\section{DISCUSSION}

In our patients with $\mathrm{CD}$ GH responses to ghrelin, GHRP-6, and GHRH were blunted, confirming earlier reports by us and others $(10,14,15)$. GH responsiveness to ghrelin was higher in CD and also in controls, which is probably due to the greater potency of this peptide compared to GHRP-6 and GHRH. The mechanisms involved in the inhibition of $\mathrm{GH}$ release in endogenous hypercortisolism remain unclear. It has been previously suggested that glucocorticoid excess inhibits hypothalamic GHRH release (14). This steroid also downregulates human GHS-R (36). Therefore, glucocorticoids could eventually interfere with ghrelin/GHS-stimulated transduction mechanisms at the somatotroph, with a possible additional effect on GHS-R located in GHRH-releasing neurons in the hypothalamus (37).

It has been previously shown that acute clinical interventions such as the inhibition of free fatty acid synthesis (20) and short-term dietary restriction (17) are able to increase GH secretion in CD. This suggests that the secretory ability of the somatotroph can be rapidly restored. Therefore, in the present study, our aim was to investigate if short-term treatment with ketoconazole was able to improve the glucocorticoidinduced GH suppression in patients with CD. In order to avoid possible GH deficiency due to previous treat- 
ment with surgery or radiotherapy, only untreated patients were included. To our knowledge there are no studies evaluating GH secretion in CD after pharmacological reduction and correction of hypercortisolism.

After one month of ketoconazole treatment all patients showed a significant reduction in urinary cortisol levels, and in $83 \%$ of the cases these values reached the normal range, as reported earlier in the literature (28). However, there were no significant differences in $\mathrm{GH}$ responses to ghrelin, GHRP-6 or GHRH before and after treatment, although a trend to increased $\mathrm{GH}$ levels after GHRH was observed. As GHS/ghrelin and GHRH activate different pathways of GH release, this could eventually indicate that GHRH-modulated mechanisms are more sensitive to the rapid decrease of circulating glucocorticoid levels. However, further studies are necessary to confirm this hypothesis.

Several studies have evaluated the GH secretory state in patients with CD in remission, after transsphenoidal surgery or radiotherapy, with controversial results, especially in adults. It has been shown that the decrease in $\mathrm{GH}$ secretion might persist for a long time in the pediatric population. GH responsiveness to arginine and L-dopa and $24 \mathrm{~h} \mathrm{GH}$ secretion are decreased in children and young adults with CD for at least one year after successful transsphenoidal surgery (24). In another study, $31 \%$ of the children with $\mathrm{CD}$, cured by surgery and, in some cases, additional radiotherapy had severe GH deficiency after insulin-induced hypoglycemia while $54 \%$ had subnormal GH responses (peak GH between 3 and $10 \mu \mathrm{g} / \mathrm{L}$ ) after 9 to 108 months of follow-up (38).

In adults results are less uniform. Improvement or normalization of $\mathrm{GH}$ responses to hypoglycemia have been shown in $30 \%$ to $100 \%$ of cases of patients with CD in remission in several large series (21-23). This variability could be due to different GH cut off values for GH deficiency and also to the type of treatment used. Patients submitted to radiotherapy had lower GH responses, probably due to pituitary damage, while $75 \%$ of the cases submitted to transsphenoidal surgery had recovery of GH responses (21). Interestingly, all patients with $\mathrm{CD}$ submitted to adrenalectomy in this study normalized $\mathrm{GH}$ responses to hypoglycemia. Moreover, it has been shown that $\mathrm{GH}$ responses to GHRH in patients with CD reverted to normal 5 to 34 years after adrenalectomy (39). Therefore, correction of hypercortisolism may lead to restoration of $\mathrm{GH}$ secretion if somatotrophs are intact.

However, our results suggest that it is likely that longer periods of normocortisolism are necessary for the recovery of normal GH secretory status also in adults. Indeed, it has been shown that $59 \%$ of patients with $C D$ in remission after transsphenoidal surgery had severe GH deficiency at an early assessment (25). However, after two years only $22 \%$ remained severely $\mathrm{GH}$ deficient. This is supported by another study which shows that patients with long-term remission of CD (mean of 8.2 years) had normal 24-hour GH secretion when compared to controls (26).

Recently, Tzanela et al. (27) found restoration of $\mathrm{GH}$ response to $\mathrm{GHRH}$ plus pyridostigminine, and also, in some cases, to hypoglycemia in $50 \%$ of patients with Cushing's syndrome in remission for 6 months, while $75 \%$ of them had normal GH responses after 18 months of follow-up. These results might explain our findings and support the hypothesis that a longer period of normocortisolism might be necessary for the recovery of GH secretory ability in these patients.

As previously demonstrated by us and by others $(10,14,15)$, our patients with CD showed exaggerated cortisol and ACTH responses to ghrelin and GHRP6. This might be due to a direct effect of these peptides on GHS-R in the tumor (18), although other mechanisms could be involved (40).

Despite a significant decrease in urinary cortisol values in all patients (mean reduction: $75 \%$ ) and normalization in $83 \%$ of them, there was no significant reduction in basal serum cortisol levels after one month of ketoconazole treatment. Our data confirms previous reports of slight serum cortisol decrease in the first weeks ( 1 to 6) of ketoconazole use (32-34), although a marked and significant reduction in urinary cortisol levels has already been described in the first week of treatment (31-33). This discrepancy might occur because of fluctuations in serum cortisol levels related to the timing of the last dose of ketoconazole, as this compound has a short half-life and a serum peak 2 hours after its ingestion. Progressive and significant reduction in basal serum cortisol levels after more prolonged periods of time were reported by some authors $(29,31,32)$.

Interestingly, in our study cortisol responses to ghrelin and GHRP-6 decreased after treatment, which shows the potent inhibition of steroid synthesis by ketoconazole. It has also been demonstrated that cortisol responses to $\mathrm{CRH}$ are decreased after ketoconazole use $(32,34)$.

After one month of ketoconazole treatment our patients showed no changes in basal ACTH levels. Although an increase in basal ACTH levels during chronic ketoconazole administration is seen in normal subjects (4l), conflicting results were reported in patients with $\mathrm{CD}$. It has been shown that in patients with CD basal ACTH levels remain unchanged (30-33,42), 
increase (34), and even decrease $(29,35)$ after ketoconazole treatment. In vitro studies were performed in order to verify a possible direct effect of ketoconazole on pituitary cells. However, results in cultures of normal rat pituitary cells were controversial. Burrin et al. (43) showed lack of effect of ketoconazole on ACTH release, while Stalla et al. (44) found a decrease in ACTH secretion, POMC mRNA and AMPc levels in these cells, suggesting a direct inhibition of the adenylcyclase system. In human pituitary adenoma cells from three patients with Nelson's syndrome, ketoconazole induced a decrease in the surface of endoplasmatic reticulum, in the density of secretion granules and of ACTH release (45). The clinical significance of these findings has never been established, and a direct pituitary effect of ketoconazole in CD seems unlikely (29).

In our study patients with $\mathrm{CD}$ had no changes in the ACTH responses to ghrelin or GHRP- 6 after one month of ketoconazole treatment. In the literature, data about ACTH responses to $\mathrm{CRH}$ during ketoconazole use in $\mathrm{CD}$ are few and controversial. Boscaro et al. (34) reported an increased ACTH response to $\mathrm{CRH}$ after 4 to 6 weeks of ketoconazole treatment, while Loli et al. (32) showed no changes in this response after 3 to 7 months of treatment.

These discrepant patterns of ACTH release during ketoconazole treatment in CD could be explained by the degree or duration of the cortisol inhibition. Theoretically, if cortisol levels decrease to subnormals levels or if cortisol inhibition is maintained for a prolonged period of time, there could be a compensatory rise of circulating ACTH released from normal corticotrophs. On the other hand, if cortisol levels are in the normal range or in the upper limit of the normality, probably they will not be a stimulus for the HPA axis, and ACTH levels will not change. A glucocorticoid agonist action of ketoconazole in the corticotrophs has been suggested, which would prevent the rise in plasma ACTH when cortisol falls (32). Therefore, the mechanisms that prevent the rise in ACTH levels during inhibition of cortisol secretion in patients with $\mathrm{CD}$ during ketoconazole treatment remain unclear.

In summary, our study shows that one month of ketoconazole treatment in patients with $\mathrm{CD}$ is not able to increase GH release after ghrelin, GHRP-6, and GHRH stimulation, despite a major reduction in urinary cortisol values. Our data also shows that basal plasma ACTH and its response to ghrelin and GHRP-6 do not change, although cortisol responses to these peptides decrease after treatment. Further studies are necessary to evaluate the effects of a more prolonged period of eucortisolism on $\mathrm{GH}$ and $\mathrm{ACTH}$ release in patients with $\mathrm{CD}$.

\section{ACKNOWLEDGEMENTS}

We would like to thank Dr. Carlos Dieguez for the initial encouragement and help. We are grateful to Ap. Filomena P. Machado and Walkiria Miranda for the technical assistance. We would like to thank FAPESP (Fundação de Amparo à Pesquisa do Estado de São Paulo, no. 02/14118-9) and CNPq (Conselho Nacional de Desenvolvimento Científico e Tecnologia, no. 300813/2003-1) for financial support. AnaMaria Judith Lengyel is a Senior Scientist of CNPq.

\section{REFERENCES}

1. Howard AD, Feighner SD, Cully DF, Arena JP, Liberator PA, Rosenblum $\mathrm{Cl}$, et al. A receptor in pituitary and hypothalamus that functions in growth hormone release. Science 1996;273:974-7.

2. Arvat $E$, di Vito $L$, Maccagno $B$, Broglio $F$, Boghen $M F$, Deghenghi R, et al. Effects of GHRP-2 and hexarelin, two synthetic $\mathrm{GH}$-releasing peptides, on $\mathrm{GH}$, prolactin, ACTH and cortisol levels in man. Comparison with the effects of $\mathrm{GHRH}$, TRH and hCRH. Peptides 1997:18:885-91.

3. Kojima M, Hosoda H, Date Y, Nakazato M, Matsuo H, Kangawa K. Ghrelin is a growth hormone-releasing hormone acylated peptide from stomach. Nature 1999;402:656-60.

4. Gnanapavan S, Kola B, Bustin SA, Morris DG, McGee P, Fairclough $P$, et al. The tissue distribution of the mRNA of ghrelin and subtypes of its receptor, GHS-R, in humans. J Clin Endocrinol Metab 2002;87:2988-91.

5. Banks WA, Tschop M, Robinson SM, Heiman ML. Extent and direction of ghrelin transport across the blood-brain barrier is determined by its unique primary structure. J Pharmacol Exp Ther 2002;302:822-7.

6. Takaya K, Ariyasu H, Kanamoto N, Iwakura H, Yoshimoto A, Harada $\mathrm{M}$, et al. Ghrelin strongly stimulates growth hormone release in humans. $J$ Clin Endocrinol Metab 2000;85:4908-11.

7. Arvat E, Maccario M, Di Vito L, Broglio F, Benso A, Gottero C, et al. Endocrine activities of ghrelin, a natural growth hormone secretagogue (GHS), in humans: comparison and interactions with hexarelin, a nonnatural peptidyl GHS, and GH-releasing hormone. J Clin Endocrinol Metab 2001;86:1169-74.

8. Popovic V, Damjanovic S, Micic D, Djurovic M, Dieguez C, Casanueva FF. Blocked growth hormone-releasing peptide (GHRP-6)-induced GH secretion and absence of the synergic action of GHRP-6 plus GH-releasing hormone in patients with hypothalamopituitary disconnection: evidence that GHRP-6 main action is exerted at the hypothalamic level. J Clin Endocrinol Metab 1995;80:942-7.

9. Popovic V, Miljic D, Micic D, Damjanovic S, Arvat E, Ghigo E, et al. Ghrelin main action on the regulation of growth hormone release is exerted at hypothalamic level. $J$ Clin Endocrinol Metab 2003;88:3450-3.

10. Correa-Silva SR, Nascif S, Lengyel AM. Decreased GH secretion and enhanced ACTH and cortisol release after ghrelin administration in Cushing's disease: Comparison with $\mathrm{GH}$-releasing peptide-6 (GHRP-6) and GHRH. Pituitary 2006;9(2):101-7.

11. Hotta M, Shibasaki T, Masuda A, Imaki T, Sugino N, Demura H, et al. Effect of human growth hormone-releasing hormone on $\mathrm{GH}$ secretion in Cushing's syndrome and non-endocrine disease patients treated with glucocorticoids. Life Sci 1988:42:979-84.

12. Leal-Cerro A, Pumar A, Garcia-Garcia E, Dieguez C, Casanueva FF. Inhibition of growth hormone release after the combined administration of GHRH and GHRP-6 in patients with Cushing's syndrome. Clin Endocrinol (Oxf) 1994;41:649-54. 
13. Borges $M H$, DiNinno FB, Lengyel AM. Different effects of growth hormone releasing peptide (GHRP-6) and GH-releasing hormone on $\mathrm{GH}$ release in endogenous and exogenous hypercortisolism. Clin Endocrinol (Oxf) 1997;46:713-8.

14. Leal-Cerro A, Torres E, Soto A, Dios E, Deghenghi R, Arvat E, et al. Ghrelin is no longer able to stimulate growth hormone secretion in patients with Cushing's syndrome but instead induces exaggerated corticotropin and cortisol responses. Neuroendocrinology 2002;76:390-6.

15. Giordano R, Picu A, Pagotto U, De lasio R, Bonelli L, Prodam F, et al. The negative association between total ghrelin levels, body mass and insulin secretion is lost in hypercortisolemic patients with Cushing's disease. Eur J Endocrinol 2005;153:535-43.

16. Leal-Cerro A, Pumar A, Villamil F, Astorga R, Dieguez C, Casanueva FF. Growth hormone releasing hormone priming increases growth hormone secretion in patients with Cushing's syndrome. Clin Endocrinol (Oxf) 1993;38:399-403.

17. Leal-Cerro A, Venegas E, Garcia-Pesquera F, Jimenez LM, Astorga R, Casanueva FF, et al. Enhanced growth hormone $(\mathrm{GH})$ responsiveness to $\mathrm{GH}$-releasing hormone after dietary restriction in patients with Cushing's syndrome. Clin Endocrinol (Oxf) 1998;48:117-21.

18. Korbonits M, Jacobs RA, Aylwin SJ, Burrin JM, Dahia PL, Monson JP, et al. Expression of the growth hormone secretagogue receptor in pituitary adenomas and other neuroendocrine tumors. J Clin Endocrinol Metab 1998;83:3624-30.

19. Korbonits M, Kaltsas G, Perry LA, Putignano P, Grossman AB, Besser GM, et al. The growth hormone secretagogue hexarelin stimulates the hypothalamo-pituitary-adrenal axis via arginine vasopressin. J Clin Endocrinol Metab 1999;84:2489-95.

20. Leal-Cerro A, Jimenez LM, Astorga R, Fernandez-Lopez I, Dieguez C, Casanueva FF. Acute pharmacological reduction of plasma free fatty acids enhances the growth hormone (GH)-releasing hormone-mediated $\mathrm{GH}$ secretion in patients with Cushing's syndrome. J Clin Endocrinol Metab 1997;82:3165-8.

21. Tyrrell JB, Wiener-Kronish J, Lorenzi M, Brooks RM, Forsham $\mathrm{PH}$. Cushing's disease: growth hormone response to hypoglycemia after correction of hypercortisolism. J Clin Endocrinol Metab 1977;44:218-21.

22. Kuwayama A, Kageyama N, Nakane T, Watanabe M, Kanie N. Anterior pituitary function after transsphenoidal selective adenomectomy in patients with Cushing's disease. J Clin Endocrinol Metab 1981;53:165-73.

23. Burke CW, Adams CB, Esiri MM, Morris C, Bevan JS. Transsphenoidal surgery for Cushing's disease: does what is removed determine the endocrine outcome? Clin Endocrinol (Oxf) 1990;33:525-37.

24. Magiakou MA, Mastorakos G, Gomez MT, Rose SR, Chrousos GP. Suppressed spontaneous and stimulated growth hormone secretion in patients with Cushing's disease before and after surgical cure. J Clin Endocrinol Metab 1994;78:131-7.

25. Hughes NR, Lissett CA, Shalet SM. Growth hormone status following treatment for Cushing's syndrome. Clin Endocrinol (Oxf) 1999;51:61-6.

26. Veldman RG, Frolich M, Pincus SM, Veldhuis JD, Roelfsema F. Apparently complete restoration of normal daily adrenocorticotropin, cortisol, growth hormone, and prolactin secretory dynamics in adults with Cushing's disease after clinically successful transsphenoidal adenomectomy. J Clin Endocrinol Metab 2000;85:4039-46.

27. Tzanela M, Karavitaki N, Stylianidou C, Tsagarakis S, Thalassinos NC. Assessment of GH reserve before and after successful treatment of adult patients with Cushing's syndrome. Clin Endocrinol (Oxf) 2004;60:309-14.

28. Engelhardt D, Weber MM. Therapy of Cushing's syndrome with steroid biosynthesis inhibitors. J Steroid Biochem Mol Biol 1994;49:261-7.

29. Sonino N, Boscaro M, Paoletta A, Mantero F, Ziliotto D. Ketoconazole treatment in Cushing's syndrome: experience in 34 patients. Clin Endocrinol (Oxf) 1991;35:347-52.

30. Angeli A, Frairia R. Ketoconazole therapy in Cushing's disease. Lancet 1985;1:821.
31. Sonino N, Boscaro M, Merola G, Mantero F. Prolonged treatment of Cushing's disease by ketoconazole. J Clin Endocrinol Metab 1985;61:718-22.

32. Loli $P$, Berselli ME, Tagliaferri M. Use of ketoconazole in the treatment of Cushing's syndrome. J Clin Endocrinol Metab 1986;63:1365-71.

33. McCance DR, Hadden DR, Kennedy L, Sheridan B, Atkinson $A B$. Clinical experience with ketoconazole as a therapy for patients with Cushing's syndrome. Clin Endocrinol (Oxf) 1987;27:593-9.

34. Boscaro M, Sonino N, Rampazzo A, Mantero F. Response of pituitary-adrenal axis to corticotrophin releasing hormone in patients with Cushing's disease before and after ketoconazole treatment. Clin Endocrinol (Oxf) 1987;27:461-7.

35. Terzolo $M$, Panarelli $M$, Piovesan A, Torta M, Paccotti $P$, Angeli A. Ketoconazole treatment in Cushing's disease. Effect on the circadian profile of plasma ACTH and cortisol. $\mathbf{J}$ Endocrinol Invest 1988;11:717-21.

36. Petersenn S, Rasch AC, Penshorn M, Beil FU, Schulte HM. Genomic structure and transcriptional regulation of the human growth hormone secretagogue receptor. Endocrinology 2001;142:2649-59.

37. Tannenbaum GS, Bowers CY. Interactions of growth hormone secretagogues and growth hormone-releasing hormone/somatostatin. Endocrine 2001;14:21-7.

38. Carroll PV, Monson JP, Grossman AB, Besser GM, Plowman $\mathrm{PN}$, Afshar F, et al. Successful treatment of childhood-onset Cushing's disease is associated with persistent reduction in growth hormone secretion. Clin Endocrinol (Oxf) 2004;60:169-74.

39. Whitehead HM, McKnight JA, Sheridan B, Kennedy AL, Hadden DR, Atkinson AB. The growth hormone response to growth hormone releasing hormone in patients previously treated with bilateral adrenalectomy alone for Cushing's disease. J Endocrinol Invest 1990;13:217-20.

40. Oliveira JH, Vieira JG, Abucham J, Lengyel AM. GHRP-6 is able to stimulate cortisol and ACTH release in patients with Cushing's disease: comparison with DDAVP. J Endocrinol Invest 2003:26:230-5.

41. Deuschle M, Lecei O, Stalla GK, Landgraf R, Hamann B, Lederbogen $F$, et al. Steroid synthesis inhibition with ketoconazole and its effect upon the regulation of the hypothalamus-pituitary-adrenal system in healthy humans. Neuropsychopharmacology 2003;28:379-83.

42. Mortimer RH, Cannell GR, Thew CM, Galligan JP. Ketoconazole and plasma and urine steroid levels in Cushing's disease. Clin Exp Pharmacol Physiol 1991;18:563-9.

43. Burrin JM, Yeo TH, Ashby MJ, Bloom SR. Effect of ketoconazole on adrenocorticotrophic hormone secretion in vitro and in vivo. J Endocrinol 1986;108:37-41.

44. Stalla GK, Stalla J, von Werder K, Muller OA, Gerzer R, Hollt $\mathrm{V}$, et al. Nitroimidazole derivatives inhibit anterior pituitary cell function apparently by a direct effect on the catalytic subunit of the adenylate cyclase holoenzyme. Endocrinology 1989;125:699-706.

45. Jimenez Reina L, Leal-Cerro A, Garcia J, Garcia-Luna PP, Astorga R, Bernal G. In vitro effects of ketoconazole on corticotrope cell morphology and ACTH secretion of two pituitary adenomas removed from patients with Nelson's syndrome. Acta Endocrinol (Copenh) 1989;121:185-90.

Endereço para correspondência:

Silvia Regina Correa-Silva

Rua Pedro de Toledo 910

04039-002 São Paulo, SP

Fax: (1 1) 5574-8432

E-mail: dra.silviaregina@terra.com.br 